\title{
Mr. Suresh and the Evil Twin
}

\author{
Audrey Mackl in
}

\begin{abstract}
In Suresh v. M inister of Citizenship and Immigration and Ahani v. $\mathrm{MCl}$, the Supreme Court of Canada declared that removing a refugee accused of terrorism to a country where he or she would face a substantial risk of torture or similar abuse would virtually always violate the individual's rights under s. 7 of the Canadian Charter of Rights and Freedoms. While the Court deserves praise for vindicating fundamental human rights over competing claims of national security, coming so close on the heels of September 11 , the victory is in certain respects more apparent than real. Given the strong endorsement of judicial deference to the exercise of $M$ inisterial discretion in national se curity matters, the Court leaves the state wide scope to circumvent the spirit of thejudgment while adhering to its letter.
\end{abstract}

\section{Résumé}

Dans les cas Suresh c. M inistre de la citoyenneté et de l'immigration, et Ahani c. $\mathrm{MCl}$, la Cour suprême du Canada a statué que le transfert d'un réfugié accusé de terrorisme vers un pays où il ou elle court des risques substantiels d'être soumis à la torture ou à des mauvais traitements similaires, violerait presque à tout coup, les droits de l'individu prévus à la s. 7 de la Charte canadienne des droits et libertés. La Cour mérite d'être félicitée pour avoir donné préférence aux droits fondamentaux de la personne aux dépens des pressions concurrentes en faveur de la sécurité nationale. Cependant, succédant de si près les événements du 11 septembre, cette victoire est, par certains côtés, plus apparente que réelle. Vu l'aval donnéà la prééminence du pouvoir discrétionnaire ministériel sur le judiciaire en ce qui concerne les questions de sécurité nationale, la Cour donne beaucoup de latitude à l'état pour contourner l'esprit du jugement tout en en respectant la lettre.

\section{Introduction}

n M ay 2001, the Supreme Court of Canada heard the appeals of $M$ anickavasagam Suresh and $M$ ansour Ahani, two refugees deemed terrorists. At stake was the power of the state under s. 53 of the Immigration Act to refoule refugees back to their countries of nationality on grounds that they posed a threat to the security of Canada. The Court reserved judgment in both cases. The Supreme Court of Canada was still deliberating on the appropriate balance between national security and human rights when the first plane crashed into the World Trade Center on September 11. The Court released its unanimous decisions in Suresh v. Canada ${ }^{1}$ and Ahani v. Canada ${ }^{2}$ on January 11 , 2002, exactly four months later.

The Canadian Supreme Court was not the only judiciary to issue decisions about refugees and security in theshadow of September 11. During this same period, the British House of Lords rendered a judgment affirming the deportation order against a Pakistani cleric alleged to constitute a national security threat. ${ }^{3}$ Around the same time the United States began bombing Afghanistan, and the Australian High Court upheld Prime M inister John Howard's policy of deflecting boatloads of Afghan refugee claimants. ${ }^{4}$

At moments of real or perceived threat to theintegrity of a democratic state, the responsibility of the judiciary to protect human rights comesunder special scrutiny. Will the Court validate the political calculus of elected officials, or will it deploy its status as an independent, unaccountable, norm-generating body to check the majoritarian tendency to compromise the rights of the few in thename of protecting the many? Without actually acknowledging their own roleas arbiters, the Court in Suresh launches its judgment by evoking the classic tension between liberty and security: 
On the one hand stands the manifest evil of terrorism and the random and arbitrary taking of innocent lives, rippling out in an ever-widening spiral of loss and fear. Governments, expressing the will of the governed, need the legal tools to effectively meet this challenge. On theother hand stands theneed to ensure that those legal tools do not undermine values that are fundamental to our democratic society - liberty, the rule of law, and theprinciples of fundamental justice- valuesthat lieat theheart of the Canadian constitutional order and the international instruments that Canada has signed. In the end, it would be a Pyrrhic victory if terrorism were defeated at the cost of sacrificing our commitment to those values. Parliament's challenge is to draft laws that effectively combat terrorism and conform to the requirements of our Constitution and our international commitments. $^{5}$

The judgments in Suresh and A hani reveal how the Supreme Court of Canada chose to situate itself at a particular historical moment. The Court selected Suresh as the lead judgment, and it contains the detailed recitation of facts and extensivelegal analysis that sustain the results in both cases. I will argue that while Mr. Suresh appears to occupy the starring role in the legal drama scripted by the Court, it is actually M r. Ahani, the "sinister" character lurking downstage and in the shadows, whose fate prefigures that of future refugees caught up in Canada's security dragnet.

\section{Background}

M anickavasagam Suresh, a Sri Lankan Tamil, entered Canada in 1990. He made a refugee claim based on his fear of persecution by the Sri Lankan government and the Liberation Tigers of Tamil Eelam (LTTE). H e was recognized as a Convention refugee in 1991, and applied for permanent resident status thereafter. $\mathrm{H}$ is application was delayed, and in 1995 the Solicitor General and theM inister of Citizenship and Immigration issued a "security certificate" under s. 40.1 of thel mmigration Act alleging that Suresh wasinadmissible on security grounds. The specific provisions under which Suresh was ultimately determined to beinadmissiblepermit the exclusion of a person who there are reasonable grounds to believe is or was a member of an organization that there are reasonablegrounds to believeis, was, or will beengaging in terrorism. ${ }^{6}$

The factual basis for the allegation was that Suresh acted as a fundraiser for the World Tamil M ovement, an organization that is either part of, or supports, the LTTE. The government took the position that the LTTE is a terrorist organization, and that Suresh was a member of it by virtue of his involvement with theW orld Tamil M ovement. At no time was Suresh accused of engaging in violent activities in Canada or abroad. Indeed, his act of fundraising was not unlawful, though this may no longer be the case under Canada's new Anti-Terrorism Act. ${ }^{7}$

The Federal Court upheld the security certificate on judicial review, and the M inister of Citizenship and I mmigration then notified Suresh that she was considering issuing a "danger opinion" declaring Suresh to represent a danger to the security of Canada. The issuance of a danger opinion by the M inister grants her discretion to order the return (refoulement) of a refugee to a country where the person's life or freedom would be threatened, thereby creating an exception to the singular protection afforded to refugees by states party to the U.N. Convention Relating to the Status of R efu gees. Counsel for Suresh contended that he would face a substantial risk of torture if returned to Sri Lanka.

A memo provided to the M inister (but not disclosed to Suresh) speculated that Suresh's high profile would render him less likely to be tortured upon return to Sri Lanka but that, even if the risk of torture was substantial, "there are insufficient humanitarian and compassionate considerations present to warrant an extraordinary consideration." ${ }^{8}$ The $M$ inister issued the danger opinion, thereby paving the way for Suresh's deportation to Sri Lanka. Suresh applied for judicial review of the danger opinion and of the inadmissibility provisions, on administrativeand constitutional grounds. Hewas unsuccessful at theFederal Court trial and appeal levels, and ultimately appealed to the Supreme Court of Canada.

Suresh challenged various aspects of the Immigration Act and the M inister's conduct. He argued that deportation to a country where he would face a substantial risk of torture violated Canada's international human rights obligations as well as s. 7 of the Canadian Charter of Rights and Freedoms. Section 7 guarantees that "[e]veryonehas the right to life, liberty and security of the person, and the right not be deprived thereof except in accordance with the principles of fundamental justice."

Suresh also contended that the terms "terrorism," "danger to the security of Canada," and "member," as employed (but not defined) in the Immigration Act, were unconstitutionally vague. He further claimed that deportation on the basis of mere membership violated the Charter rights to freedom of expression (s. 2(b)) and association (s. 2(d)).

Apart from the defects in the legislative scheme, Suresh also argued that the Minister owed him a duty of fairness in the exercise of her discretion, and she had breached that duty by failing to give him a proper hearing, disclosure of the evidence against him, and reasons for her decision to refoule him to Sri Lanka.

Mansour Ahani, an Iranian national, entered Canada and acquired refugeestatus in 1991. The C anadian Security 
and Intelligence Service (CSIS) formed the opinion that Ahani was a trained assassin for the Iranian M inistry of Intelligence Security (M OIS). A hani met with CSIS agents upon return from a trip to Europe, and allegedly admitted to them that he had met with a former M OIS associate. In June 1993, the M inister of Citizenship and Immigration and the Solicitor General issued a certificate declaring Ahani to be inadmissible both as a member of a terrorist organization and as one who there are reasonable grounds to believe has engaged or will engage in acts of terrorism or violence that "would or might endanger the lives or safety of persons in Canada." 9 Pursuant to legislative authority, Ahani was arrested in 1993 and has remained in custody ever since.

As between the two men, Suresh was clearly the more sympathetic appellant: As a T amil, he belongs to a minority that has experienced systematic and often brutal discrimination and oppression by the Sinhalese majority and government. As noted earlier, he was not directly associated with violence. Accompanied by many supporters from the Canadian Tamil community, Suresh attended his hearing before the Supreme Court of Canada. Moreover, eight interveners lent their support and credibility to his appeal, including the United Nations High Commissioner for Refugees, Amnesty International, and the Canadian Bar Association.

In contrast, Ahani was an alleged political assassin employed by a widely reviled regime. Unsurprisingly, he was not a popular man in the Iranian community, many of whom had fled the current government. $\mathrm{N}$ ot a single intervener in Suresh participated in A hani, even though thelegal issues (and even legal counsel) wereidentical in both cases. Ahani remained in detention on the day of his hearing, an absent presence before the Court.

There are many layers to the decisions in Suresh and Ahani. One may begin with a description of the form in which the judgments were rendered. Both were delivered unanimously under the collective authorship of the Court. Decisions issued by "the Court," rather than under the name of the judge who authored it, are usually reserved for cases that not only raise contentious issues, but which also have the potential to becomeflashpoints for debate over the legitimacy of judicial review in a democracy. ${ }^{10}$ Arguably, Suresh did not raise issues that were intrinsically more "political" than many other cases; nevertheless, the timing of the decision ensured that it would attract controversy. Theimage of a united Court potentially reduces the scopefor politicizing the judgment by withholding alternative legal analyses from critics. It also precludesthe tactic of telescoping criticism onto thepersonality of theauthor, thereby confining detractors to a broad institutional critique of the Court.

\section{Deportation and Torture}

The starkest question before the Court was whether returning a non-citizen to a country where he or she faced a substantial risk of torture violated fundamental human rights obligations binding upon Canada. But which human rights obligations? Canada is constrained from without by international law. It is constrained from within by Canada's own constitutional commitments asarticulated in the Canadian Charter of Rights and Freedoms.

Both the International Covenant on Civil and Political Rights (ICCPR) and the Convention against Torture (CAT) prohibit deporting an individual to torture. Canada ratified the two instruments in 1976 and 1987 respectively. The Supreme Court of Canada adopted the CAT definition of torture and, subsequent to Suresh, the government incorporated the CAT definition into the new Immigration and Refugee Protection Act. It states as follows:

Article 1 of the Convention against Torture and Other Cruel, Inhuman and Degrading T reatment or Punishment

1. For the purposes of this Convention, torturemeans any act by which severe pain or suffering, whether physical or mental, is intentionally inflicted on a person for such purposes as obtaining from him or a third person information or a confession, punishing him for an act heor a third person has committed or is suspected of having committed, or intimidating or coercing him or a third person, or for any reason based on discrimination of any kind, when such pain or suffering is inflicted by or at the instigation of or with the consent or acquiescence of a public official or other person acting in an official capacity. It does not include pain or suffering arising only from, inherent in or incidental to lawful sanctions.

2. This article is without prejudice to any international instrument or national legislation which does or may contain provisions of wider application.

In addition to the CAT and other international instruments, a considerable body of state practice and international authority support the contention that an absolute prohibition on torture is a peremptory norm of customary international law (jus cogens), which binds Canada independently of any treaty obligation. ${ }^{11}$

M eanwhile, s. 7 of the Charter guarantees to everyone "the right to life, liberty and security of the person and the right not to be deprived thereof except in accordance with theprinciples of fundamental justice." In thelandmark case of Singh v. M inister of Employment $\&$ Immigration, ${ }^{12}$ the SupremeC ourt of Canada ruled that sending refugeeclaimants back to their country of origin would jeopardize their s. 7 right to security of the person. In Suresh, the issue was 
whether s. 7 if the Charter permitted return of a person to face torture if he was found to be a security risk in Canada.

In the course of the judgment, the Court diminishes the authoritative force of international law by implying that Canada's treaty obligations regarding torture had never been formally incorporated into Canadian law, and thus do not bind Canada. ${ }^{13}$ The Court also shies away from according the prohibition on torture the status of jus cogens. ${ }^{14}$ Further, the Court asserts that, in any event, it is the Charter, and not international law, which supplies the normative standard against which Canadian law will be measured:

Our concern is not with Canada's international obligationsqua obligations; rather, our concern is with the principles of fundamental justice [under s. 7]. We look to international law as evidence of these principles and not as controlling in itself. ${ }^{15}$

One might reasonably contend that it matters little whether the Court takes the route of international law or the Charter if the destination turns out to be the same. N evertheless, the subordination of international law to the role of interpretive tool for domestic law reveals a certain symmetry between who decides the terms of entry into the country and who determines the terms of entry into the legal order. In both cases, the answer is national authorities, acting according to domestic law.

Policing the borders is seen as a matter of national sovereign control, and to the extent that the UN Convention Relating to the Status of Refugees shears this power, interpreting the available exceptions to the duty to admit refugees emerges as a site for reclamation of control. Domesticating international law through the Charter means that Canadian law remains answerable ultimately only to Canadian law, as interpreted by Canadian judges. Because the Supreme Court of Canada provides the final word on Canadian law, international treaty bodies (such as the UN Committee against Torture) that advisestates party of the scope of theinternational norm, do not challenge the SupremeCourt of Canada's interpretive monopoly. As if to reinforce their dominion, the Supreme Court of Canada declined to hear a subsequent appeal by Ahani that his deportation should be stayed pending the outcome of his application to the UN Human Rights Committee for consideration as to whether his human rights under the UN Covenant on Civil and Political Rights would be violated upon return to Iran. A majority of the Ontario Court of Appeal ruled that S. 7 of the Charter did not require the Canadian government to await the communication of the $H$ uman Rights Committee and take its views into account before proceeding with the deportation. ${ }^{16}$
In itss. 7 analysis, the Court rules that deporting a person to a country where he or she faces a substantial risk of torture will virtually al ways violatethelife, liberty, and security of the person in a manner that doesnot comport with fundamental justice. The Court emphatically rejects the government's attempt to evade responsibility for what another country might do to a deportee. Instead, it affirms that:

... whereCanada's participation is a necessary precondition for thedeprivation [ of life, liberty, and security of the person], and where the deprivation is an entirely foreseeable consequence of Canada's participation, the government does not avoid the guarantee of fundamental justice merely because the deprivation in question would be effected by someone else's hand." ${ }^{17}$

This constitutional accountability for complicity in the human rights violations of actors beyond the reach of the Charter warrants closer scrutiny, for the Court tacitly admits that the polycentric matrix dubbed "globalization" creates not only economic and security interconnections, but also networks of moral responsibility. ${ }^{18}$

The Court concludes that the M inister "should generally decline to deport refugees where on the evidence there is a substantial risk of torture."19 Although it allowed for the theoretical possibility of departures from the rule, the Court declines to articulate any examples, saying only that "theambit of an exceptional discretion to deport to torture, if any, must await future cases." 20

A year prior to Suresh, the Supreme Court of Canada reversed earlier s. 7 jurisprudence by ruling that the $M$ inister of Justice could not normally extradite a fugitive to face the possibility of capital punishment in the United States without requesting assurances that the death penal ty would be neither sought nor imposed. ${ }^{21}$ In light of this decision in Burnsand Rafay, thefinding that deportation to facetorture would also violate s. 7 is perhaps unsurprising, though no less salutary for that reason.

The determination that Canada may not generally deport a person to face torture represents the climax of the legal narrative. To grasp itssignificancein thereal lifestories of refugees who come after Suresh, one must attend to some of the Court's less dramatic pronouncements, and the way in which they steer Ahani's appeal toward its resolution.

\section{Interpretation and Discretion}

The path to refouling a refugee is paved with a series of discretionary rulings by the Minister. It begins with the $M$ inister issuing a certificate labelling the refugee inadmissible as a terrorist, either because of his or her own past, present, or future "terrorist" actions or due to membership in a "terrorist" organization. This finding must beupheld as 
"reasonable" by a reviewing judge of the Federal Court. The next step involves an opinion by the M inister under $\mathrm{s}$. 53 of the Immigration Act that the refugee poses a threat to the security of Canada on account of terrorism. From there, the $M$ inister makes a finding about the consequences of refoulement, which in turn grounds the balancing exercise between Canada's security and the likely fate of the refugee upon return. Only in circumstances where the person concerned faces a substantial risk of "torture or similar abuse" 22 will the Charter generally prohibit refoulement.

One need never confront the prospect of refouling a refugee if the refugee is not a "terrorist," or does not pose "a danger to the security of Canada." M ore insidiously, one need not engage in the exercise of balancing Canadian security against the likely torture of a human being if the $M$ inister concludes that what awaits the refugee constitutes some lesser harm. In the result, the legal content of the terms "danger to security of Canada," "terrorism," and "membership" become crucial filtering mechanisms, as does the process by which the Minister determines the nature of the risk facing the refugee.

Counsel for the appellants and several interveners argued strenuously that "terrorism" is an ineluctably political term and unconstitutionally vague in its ambit. The Immigration Act does not define it, and the Federal Court consistently refu sed to interpret theterm, preferring instead the "I know it when I see it" approach. According to theappellants and some interveners, "terrorism" does not admit of a neutral conceptual definition. At best, it can only be defined functionally, by reference to specific prohibited acts, most of which are criminal in any event.

The Supreme Court of Canada acknowl edges these critiques, but ultimately is "not persuaded ... that the term 'terrorism' is so unsettled that it cannot set the proper boundaries for legal adjudication." 23 The Court ad opts the definition employed in the recent International Convention for the Suppression of the Financing of T errorism, ${ }^{24}$ and defines terrorism for purposes of the Immigration Act as:

Any act intended to cause death or serious bodily injury to a civilian, or to any other person not taking an active part in the hostilities in a situation of armed conflict, when the purpose of such act, by its nature or context, is to intimidate a population, or to compel a government or an international organization to do or to abstain from doing any act. ${ }^{25}$

While acknowledging room for disagreement at the margins, the Court feels confident that this definition captures "theessence of what the world understands by 'terrorism'," 26 though Parliament is not precluded from adopting an alternative definition. ${ }^{27}$
One may cavil over the Court's definition of terrorism, but at least the Court confines its scope to acts of serious violence. Unfortunately, theCourt does littleto clarify what it means to be a member of a terrorist organization, which is the provision used to label Suresh a terrorist. The Court indicates only that "member" encompasses "persons who are or have been associated with things directed at violence, if not violence itself," while excluding those who associate with (or contribute to) organizations in ignorance of the group's terrorist activities. ${ }^{28}$ Replacingthenoun "member" with theverb "associate" is distinctly unhelpful, especially since the Court declines to elaborate upon the indicia of association.

The opacity of the Court's discussion of membership is revealed by the fact that the judgment does not explain whether or how Suresh's fundraising activities for the World Tamil Movement (WTM) were sufficient to make him a member of the LTTE. Nor is it evident what conclusion the Court ought to draw in light of its definition, though one might infer by its silence that the Federal Court did not err in upholding the certificate which found Suresh inadmissible on the basis of membership. Nevertheless, if one cannot confidently apply a definition developed in the context of an appeal to the actual fact situation presented in the case, one might conclude that the definition is rather unsatisfactory. Of even greater concern is the fact that the potential breadth of an imprecise definition of membership eviscerates the virtue of a relatively narrow definition of terrorism. Few persons may engage in "terrorist" activities, as terrorism is defined, but a great many may be caught in the expansive sweep of "membership" in an organization that engages in terrorism.

The finding of inadmissibility based on membership in a terrorist organization forms the basis of a Ministerial opinion that the person poses a "danger to the security of Canada." The Court resists the claim that risks to Canadian security include only those activities that pose a threat to Canada and not another country, ${ }^{29}$ stating simply that whatever the justification for this limitation in the past, "after the year 2001, that approach is no longer valid."30 Rejecting the argument that "danger to the security of Canada" is unconstitutionally vague, the Court furnishes the following definition:

While the phrase "danger to the security of Canada" must be interpreted flexibly, and while courts need not insist on direct proof that the danger targets Canada specifically, the fact re mains that to refoule a refugee... to torture requires evidence of a serious threat to national security. To suggest that something less than serious threats founded on evidence would suffice to deport a refugee to torture would be to condone unconstitutional application of the Immigration Act. ... 
These considerations lead us to conclude that a person constitutes a "danger to the security of Canada" if he or she poses a serious threat to the security of Canada, whether direct or indirect, and bearing in mind the fact that the security of one country is often dependent on the security of other nations. The threat must be "serious", in the sense that it must be grounded on objectively reasonable suspicion based on evidence and in the sense that the threatened harm must be substantial rather than negligible. ${ }^{31}$

In principle, thefinding of inadmissibility on grounds of terrorism does not prove that the refugee poses a danger to the security Canada, since s. 53 requires that the person must be inadmissible and that "the M inister is of the opinion that the person constitutes a danger to the security of Canada." O nemight speculate that a person who is deemed inadmissible on the basis of an attenuated association with an organization that carries on diverse activities (ranging from provision of social services to violence) might not necessarily pose a danger to the security of Canada. The Court declines the opportunity supplied by the factual context in Suresh to provideguidance on this matter. Suresh was a fundraiser for the World Tamil M ovement, not the LTTE, but the judgment does not explore the actual relationship between the WTM and the LTTE, or explain why it is sufficient to constitute membership in a terrorist organization.

\section{Standard of Review and Procedural Fairness}

The Court undertakes to give legal content to "danger to the security of Canada," "terrorism," and, to some extent, "membership" in order to thwart the claim that the terms are unconstitutional ly vague, or violate the Charter guarantees of freedom of expression (s. 2(b)) and association (s. 2(d)). In so doing, the Court constrains the ability of the M inister and the Department of Citizenship and Immigration to arbitrarily attach those designations to individuals. Section 7's virtual prohibition on deporting a person to face torture similarly circumscribes $\mathrm{M}$ inisterial discretion.

What remains, however, is the M inister's discretion to formulatean opinion about whether the refugee is a danger to the security of Canada and whether the risk faced upon return equals torture or similar abuse. How closely should the courts scrutinize the M inister's exercise of discretion? The Supreme Court makes it clear in Suresh that both decisions warrant maximum deference. $W$ ith respect to the first, the Court quotes approvingly from a recent House of Lords decision, Secretary of State for the H ome Department v. Rehman, ${ }^{32}$ in which Lord Hoffman declared that the events of September 11 "underline the need for the judicial arm of government to respect the decisions of ministers of the Crown on the question of whether support for terrorist activities in a foreign country constitutes a threat to national security." 33 The Court concludes that it should follow its British cohort and:

... adopt a deferential approach to this question and set aside the Minister's discretionary decision if it is patently unreasonable in the sense that it was made arbitrarily or in bad faith, it cannot be supported on the evidence or the Minister failed to consider the appropriate factors. The court should not reweigh the factors or interfere merely because it would have come to a different conclusion. ${ }^{34}$

Regarding the standard of review of the M inister's decision regarding the consequences of deportation, the Court describes the assessment as "in large part a fact-driven inquiry." 35 The M inister may consider a range of factors, including the human rights record of the home state, the personal risk faced by the refugee, the ability of the home state to control its security forces, the availability of another state to accept the refugee, etc. According to the Court, this evaluation by the $\mathrm{M}$ inister attracts deference from reviewing courts, and can only be set aside if, once again, "the decision isnot supported by theevidenceor failsto consider the appropriate factors." ${ }^{36}$

Despite the high stakes of deportation, the Court is confident that "a deferential standard of ministerial review will not prevent human rights issuesfrom being fully addressed, provided proper procedural safeguards are in place and provided that any decision to deport meets the constitutional requirements of the Charter." ${ }^{37}$ What are the proper procedural safeguards? According to the Court, the re quirements of fairness fluctuate with the risk facing the refugee - the greater the potential harm, the more fairness due the individual.

In effect, the refugeemust "establish a threshold showing that a risk of torture or similar abuse exists before the Minister is obliged to consider fully the possibility." 38 Where a refugee makes out this prima facie case, the $\mathrm{M}$ inister must providethe refugee with notice of the caseagainst him or her, an opportunity to respond in writing, and substantive, written reasons for the decision. Suresh had madeout such a prima faciecase, and since the M inister had provided Suresh with no opportunity to respond to the case against him (as contained in the memo to the M inister), much less reasons for her decision, Suresh's appeal was allowed and the case was remitted back to the M inister for consideration in conformity with the requirements of procedural fairness.

And so the story of Mr. Suresh appears to have a happy ending, or at least a hopeful ending: $\mathrm{H}$ aving [fortuitously] 
established a prima facie risk of torture, the failure of the Minister to disclose her assistant's memo and provide Suresh right of reply, as well as her refusal to supply written reasons for her decision, breached a duty of fairness owed to Suresh. Thus, he is entitled to a new hearing before the $M$ inister, and a reasonableinferencefrom the Court's judgment is that Suresh's "terrorist" membership qua fundraiser would not justify an exception to the general prohibition against refouling a refugee to face torture.

But what of Mr. Ahani? The Court has little difficulty disposing of his appeal. Ahani had not established a prima facie case that he would be exposed to torture upon return to Iran; therefore, he was not entitled to know and respond to the contents of the memo to the M inister. Nor was he entitled to reasons for the decision to deport him. The Court concludes that the M inister had properly exercised her discretion in arriving at the opinion that Ahani posed a danger to thesecurity of Canada and that therisk to Canada by his remaining outweighed whatever risk faced him in Iran. Her decision was not patently unreasonable and therefore warranted judicial deference.

Of course, Ahani would have had no way of knowing at the timehe madehis submission to the M inister that hewas required to demonstrate a prima facie risk of torture in order to attract a duty of fairness. Section 53 is silent regarding procedural protections, and places no limits on the M inister's power to deport. The limitation regarding deportation to torture was "read in" to the legislation via s. 7 of the Charter. In dismissing his appeal, the Supreme Court of Canada effectively found that Ahani had failed to meet a standard that did not yet exist as a prerequisite to obtaining procedural protections that had never been provided in the past, which were to be implemented in exercising discretion for which no limiting factors had yet been articulated.

One cannot but wonder whether rejecting this M iddleEastern man, alleged to be a hired assassin for a brutal Islamist regime, provided a useful counterweight to the relatively favourable outcome for Suresh, whose activities were non-violent and not even unlawful at the relevant time. Permitting an [indirect] fundraiser to remain in Canada is surely less controversial than the prospect of allowing a hired assassin to stay indefinitely because he might be tortured if returned to his country of nationality. What better way to convey an image of transcendent judicial neutral ity and perfect balance between liberty and security than a tie score - refugee 1: government 1.

But of course, there will be other non-citizens who come after M r. Suresh and M r. Ahani. Some will be refugees who face persecution, torture, or death if returned. What do the decisions in Suresh and Ahani presage?
After Suresh, a decision to deliberately deport a person to face a substantial risk of torture will (or should) comeat a high political cost. On the other hand, thanks to A hani, if the $\mathrm{M}$ inister determines that the individual has not made out a prima facie case of torture, there is no requirement to inform the refugee of the caseagainst him or her, to provide the refugee with an opportunity to respond to the evidence marshalled against him or her, or to provide reasons for the decision. Even if the M inister concedes that a prima facie case has been established, the M inister can still decide that after careful review, the evidence does not support a substantial risk of tortureor similar abuse. Suresh confirmsthat each of these interim exercises of discretion will be subject to the most deferential standard of review, meaning that the exercise of discretion must be "patently unreasonable" to warrant judicial intervention. In practice, no one will be returned to face a substantial risk of torture if the $\mathrm{M}$ inister al ways forms the opinion that the evidence is insufficient to establish a substantial risk of torture, and if the courts systematically defer to the M inister's assessment of that risk.

After September 11, Canada passed a new Immigration and Refugee Protection Act, as well as the Anti-Terrorism Act. The latter was in direct response to September 11. The new immigration legislation does not materially alter the process to which Suresh and Ahani were subject, and I suspect that deportation under immigration law will bethe instrument of choice (rather than criminal prosecution under the Anti-Terrorism Act) where the suspect is a noncitizen.

I expect that September 11 will result in more refugees being entangled in the security web in the future. When the Court declares in Suresh that "Parliament's challenge is to draft laws that effectively combat terrorism and conform to therequirements of our Constitution and our international commitments," they omit to add that the judiciary's task is to ensure not only that those laws are constitutional on paper, but also to scrutinize the implementation of those laws so that human lives do not fall through the cracks of discretion into a dark space where the law does not reach.

\section{Notes}

1. 2002 SCC 1 [hereafter cited by paragraph number].

2. 2002 SCC 2.

3. Secretary of State for the H ome D epartment v. Rehman, [2001] 3 WLR 877.

4. Vadarlis v. M IM A and Ors, M 93/2001 (27 November 2001).

5. Para. 4.

6. Immigration Act, ss. 19(1)(f)(iii)(B) and 19(1)(e)(iv)(C).

7. Anti-Terrorism Act, S.C. 2001, c.41.

8. Para. 16. 
9. Immigration Act, ss. 19(1)(e)(iii), 19(1)(e)(iv)(C), 19)(1)(f)(ii), 19(1)(f)(iii)(B) and 19(1)(g).

10. Examples include the Reference re Secession of Quebec, [1998] 2 SCR 217; Daiglev. Tremblay, [1989] 2 SCR 530.

12. [1985] 1 SCR 177.

13. Para. 60 . One might counter that $\mathrm{s} .12$ of the Charter, which prohibits cruel or unusual treatment or punishment, and $\mathrm{s}$. 269.1 of the Criminal Code effectively incorporate the treaty prohibition.

14. Paras. 62-65. If the prohibition on torture cannot satisfy the test for jus cogens, one may well question whether any human rights norm ever could.

15. Para. 60.

16. Ahani v. M inister of Citizenship and Immigration, [2002] O] No. 81 (CA). Leave to appeal to the Supreme Court of Canada denied, 17 M ay 2002.

17. Para. 54.

18. The principle also creates the potential for holding the state accountable for the foreseeable human rights consequences of privatization, or the delegation of state power to non-state actors.

19. Para. 77.

20. Para. 78.

21. United States v. Burns, [2001] 1 SCR 283, overruling Kindler v. Canada (M inister of Justice), [1991] 2 SCR 486.

22. Para. 126.

23. Para. 96.

24. GA Res. 54/109. 9 December 1999, Annex, Art. 2.

25. Para. 98.

26. Para. 98.

27. Parliament had, in fact, already incorporated a much more extensiveand potentially expansivedefinition in theAnti-Terrorism Act, passed 28 November 2001 (Bill C-36). On theother hand, thenew Immigration and RefugeeProtection Act does not define terrorism.

28. Paras. 108, 110.

29. Paras. 85-87. The Court was responding to arguments presented in J. H athaway and C. H arvey, "Framing Refugee Protection in the New World Disorder," (2001) 34 Cornell Int'l L.J. 257, 289-90.

30. Para. 87. The Court elaborates by setting out the global nature of terrorist networks, and the need for international cooperation to respond to existing and future threats. Para. 88.

31. Paras. 89-90.

32. [2001] 3 WLR 877.

33. Quoted at Para. 33.

34. Para. 29.

35. Para. 39.

36. Para. 40.

37. Para. 32.

38. Para. 127.
Audrey M acklin is associate professor of law at the University of Toronto. $\mathrm{H}$ er research areas include immigration and refugee law, culture and law, and feminist jurisprudence. From 1994-96, she was a member of the Convention Refugee De termination Division of Canada's Immigration and Refugee Board. She was also counsel to one of the interveners ( $C$ anadian Arab Federation) in theSuresh case. This paper was first presented at a conferenceentitled "Peacekeeping or Gatekeeping: Canadian Security Policy after September 11," hosted by the York Centre for Security Studies at York University on February 7 and 8, 2002. 